UDC 159.9.01:316.6

DOI: $10.26565 / 2410-1249-2020-14-02$

\title{
AT THE FOREFRONT OF THE BUFFER: THE CONVERGENCE OF TRADITIONAL AND POSITIVE PSYCHOLOGY
}

\author{
이 Pavel Lushyn \\ ${ }^{I}$ State higher educational institution «University of Educational Management» of NAES of Ukraine \\ Education and Scientific Institute of Management and Psychology \\ Department of Psychology and Personal Development \\ Sichovykh Striltsiv Str. 52 A, Kyiv, 04053, Ukraine \\ e-mail:plushyn@gmail.com; https://orcid.org/0000-0002-9549-1759
}

\begin{abstract}
The paper provides a holistic or rather a holographic representation of the evolution of a segment of psychological disciplines in the period of its critical self-organization within a so called VUCA-world (volatile, unpredictable, complex and ambiguous). The basic contradiction between Traditional and Positive Psychology are interpreted in terms of a source of development of a novel sphere of psychological research and practice called by the author Buffer or Transition Psychology. Its content is viewed through dialectical, psycho-immunal and clinical perspective. An original non-deficiency principal is defined and illustrated by a case of a severely traumatized woman: within one session she positively resolutes into a posttraumatic growth condition. The author raises challenging issues which open up promising discussions and practical implications into psychological and social research.

KEYWORDS: VUCA-world, Positive Psychology, Traditional Psychology, Buffer/Transition Psychology, psychological practice, non-deficiency principal, ecosystem, social psychoimmunity, ecofacilitation, post-traumatic growth.
\end{abstract}

Problem statement. The psychological community as well as consumers of psychological knowledge has encountered an unprecedented situation that changed the whole understanding of the perspectives of the research and practice in the field. Psychology usually meant to deal with predominantly negative experiences was limited to offer therapy of psychiatric problems. M. Seligman (2000) and M. Csikszentmihalyi (2012) were among the first to find that humans do not just want to be free of the problem, they also crave for happiness. Being experts in the study of optimism and flourishing they pioneered a paradigm shift known as Positive Psychology, which is associated with the study of happiness, wellbeing: it is "not intended to replace or eliminate suffering, disadvantage or disruption (soul), but rather to add to the Treasury or to enrich, as well as to understand scientifically about the human experience" (Toriqul, 2018). Since the emergence of Positive Psychology mental health as the absence of illness and its prevention and treatment has no longer remained the major concern and priority of psychological research and practice.

\section{Analysis of the research and literature}

The updated version of the science has become so called "the second wave of Positive Psychology" (PP2.0). Its proponents reconsider understanding of the positive understanding the dialectical connection between health and illness, wellbeing and suffering (Fava, 2020; Held, 2004; Miller, 2008; Lomas, 2015, Wong, 2017). «In recent years, we have witnessed a number of positive psychologists debunking the myths of PP (BiswasDiener, 2013; Francis, 2012; Marsh, 2013; C. Peterson, 2012) as if these myths were merely due to misunderstandings and misapplications; but these problems are, in fact, symptoms of the fundamental problem of scientism. Against this backdrop, PP 2.0 is directly aimed at these errors. Scientism is replaced by a humble science (Templeton, 1998), because truths about human behavior and the human condition come from different paradigms of truth claims, from phenomenological research and philosophical inquiries. Positivism is replaced by a pluralistic perspective. Elitism is replaced by valuing the voice of research participants (Gergen, 2016; Wong, 2016a) and the "big tent" grassroots approach of 
valuing research from different disciplines. Thus, the emergence of PP 2.0 promises a very different kind of research, as well as interventions that are more relevant to real life for people in all cultures» (Wong, 2017).

Basically we witness the appearance of a "third thing", or in terms of dialectics a synthesis between traditional Psychology and forms of Positive Psychology which are not about a clear understanding of illness or health, negative or positive, normative or pathological, but a sphere of a dialectical transition or a buffer which is characterized by a change in determination, a direction of which is the progress from a linear into a non-linear marked by ambiguity and chaos. That is why further we consider appropriate to join those authors that view the current situation of social and personal development as Volatile, Unpredictable, Complex and Ambiguous (VUCA-world) (Lushyn, 2017; Bauman, 2010; Mack, 2015) in which the changes are rapid and very difficult to adjust to. The new reality supports the importance of elaborating technologies which help utilize the situation of uncertainty in a manner not only tolerated but beneficial for the sake of the development and growth. This technology could be described in terms of "technology of uncertainty" or as it described in one of the Slavic sayings "to go there not know where, bring me what know not". Conceptually speaking it is about the use of the non-linear model of transition, the linear model being that when the subject moves from point $A$ to a certain point $B$, the non-linear represents a process where the destination point is ambiguous or characterized as a "paradoxical attractor", i.e. a form of stability or a space for new possibilities. The phenomenon is conceptualized inI. Prigogine's works (1984) as "unpredictable stabilization"/“order through chaos" or in the synergies research - as a self-organization of open systems (Kenny, 1988; Wieland-Burston , 2015).

However, the Prigogine's "order through chaos" paradigm of change as well as synergistic research and our own early studies of the personal change processes were mainly directed at control and management of chaotic and ambiguous situations viewed in deficiency terms of a "pathology" to be eliminated (Lushyn, 2013; Greenberg, 2010;
Masterpasqua, 1997). According to a non-deficiency approach and dialectical perspective the elimination of chaos and ambiguity is neither possible nor appropriate, both are deeply imbedded into the course of system's development: if order is associated with conservative tendency and chaos with a destabilization and change features, then the progressive transformation turns up as a resolution of the contradiction between the two. In a sense the more stabilized is an open system, the more it is reluctant to develop the traits of self-exhaustion and stagnation, as well as a further growth of instability with signs of chaos and ambiguity (Lushyn, 2017; Greenberg, 2010; Linden, 2020; Rowen, 1992). In this context the positive attitude to chaos and ambiguity - which is intolerance for certainty - can paradoxically lead to its opposite which is order and certainty, although on a different level of development.

The latter helps to confirm the following: a) the ontological status of the open system (Pervin, 1990; Von Bertalanffy, 1967) is a constant communication with an outside world by means of generating and expansion of its boundaries or transitional forms; b) illness and health, pathological or normative experience can be conceptualized in progressive terms of the stability of constant change or the flow of emergents. For example, we can assume that a healthy individual is not the one who doesn't fall ill but the one who recovers (the model of "chronic health").

If we define the relation between the two states within a model of a "chronic illness" (a healthy individual/a system is not the one that doesn't fall ill but never recovers, i.e. is empowered by a constant search of change or the emergence of new possibilities), then there follows that the state of illness demands a certain "healthy condition"/a resource" or a creative potential for a relative/temporary recovery of the subsequent "remission" or growth. Thus, the "chronically healthy" person can be redefined as a dynamic open system that having even reached a higher level of functioning, chooses to open up in front of the alternative to rather grow and develop, then to stagnate: "To be defeated without submission is a victory. To win resting on one's laurels is a defeat" 
(City of translators, 2007). Consequently, to stay healthy is to appropriate/assimilate a capacity for transcending both illness and health for the sake of progressive realization of the imbedded potential. For example, it is well known that the amount of absolutely healthy people is gradually decreasing, while life expectancy - due to the technological revolution and other factors like change in nutrition and education-is rising. Paradoxically the appearance of new illnesses and disorders as well as their reinterpretation promotes the discovery of innovative spheres of treatment like psychosomatic medicine and psychology, bioengineering and digital medicine. Actually, we are dealing with not just a different concept of health (as development) but with a progression of the human identity which is Homo Transitorius.

\section{Aim of the paper}

The aim of the paper is to analyze theoretical as well as some empirical background for distinguishing a special sphere of psychology with its major task to resolve the contradiction between Traditional (Negative) and Positive Psychology by claiming that both are complementary as well as dialectically interdependent predispositions for the change and development of socio-cultural matrix of psychological knowledge.

\section{Methods of the research}

Analysis, synthesis, the empirical part of the research used the case study within an extended period of psychological practice by means of original therapeutic modality of eco-centered facilitation (Lushyn, 2017; Lushyn, 2013).

\section{Principal results of the research}

Dialectical model of socio-psychological immunity, and wellbeing. The traditional understanding of health and well-being is interpreted in terms of a deficit or rather a break in fullfunctioning of an organism, mental or social system, a person or a group. Consequently, to treat the system or an ecosystem of closely connected substructures and elements means to either directly restore it by replacing the old or broken parts or to indirectly immerse it into a set of conditions under which the system starts to operate correctly. Further we will dwell on another approach to healing/treatment associated with the holistic concept of health understood in terms of non-deficiency of the systems potential as well as its developmental/transitional nature. We call this approach dialectical immunity model or socio-psychological immunity model (SPI) (Lushyn, 2017; Davis, 1994) the essence of which lies in the fact that mental, social and physical organisms being closely interconnected constitute a self-regulated and self-organized ecosystem with a potential not only to fight deficiency of internal or external origin-as traditionally is ascribed to an organism's immune system - but also to facilitate its growth and development, as well as thriving and stagnation. By this we underline that the sociopsychological immunity is not only a defensive but proactive/creative entity. That means that the course of development is determined by the resolution of the basic contradiction between stability and change: as soon as the first start to prevail (and there appear definite signs of system's stagnation), the second tendency takes a lead in order to generate novel contexts to be mastered (Kostyuk, 1989). Consequently, an intent to present an open system as stable and absolutely predictable reduces its understanding to an inanimate or mechanic. In terms of SPI the only form of sustainability as a major quality of full-functioning and health is development, i.e. a constant change of emergents and novel forms of existence.

In the context of SPI the work of an immune system functions as scarcely predictable, irreversible and non-linear process. That presupposes that we are not able to guaranty at what time and in what locality the system enters the situation of survival or change as well as it is quite problematic to predict at what level, physical, mental or social, the change will unfold. SPI is a distributed subsystem with a capacity to function non-locally. The scarcely limited spectrum of response can occur at any place and on any level: the subject being at impasse or restricted in treatment or self-healing can apply to a distributed/systemic resource including even international by means of modern technology and forms of communication. Consequently, applying for a social assistance is not case of individual treatment or help but an act of selfregulation on a social level of SPI.

T-he SPI also operates as an open and irreversible subsystem of an organism or psychological/social 
entity meaning it can never restore the former level of functioning even if the existing markers of stability may become evident. Following this logic, the disorder/illness is not necessarily about deconstruction or extinction but rather a transition to new possibilities and levels of functioning. That also means that any attempt to stabilize the system in terms of an object/mechanistic type of change - by reducing its qualities to a preexisting condition would rather mean depriving the system of its organic nature and thus treating it as a plant growing in a greenhouse (Smith, 2008). (On the one hand the organism stays protected, on the other - it may develop a deficiency of the immune system or an inability to fight external factors.)

In the context a condition of illness and a condition of health are normative, and in dialectical perspective are related to each other as "thesis-antithesis" in the course of generating a synthesis of new emergents and capacities. Following this, disorderly as well as healthy functioning are transitional, complementary (Hegel, 1812; Mills, 2000; JansBeken, 2019).

Thus, it is assumed that encountering the complex, problematic situations can cause adequate immunity response that facilitates not just a relief or an adjustment but also strengthening of the sociopsychological immunity in the form of new "antibodies" (within immune as well as dialectical logic: gene-antigene-anti-body or thesis-antithesissynthesis). Metaphorically speaking the experience of living through the situations may build a "bank of anti-bodies" or socially relevant culture of capacities and self-healing trajectories.

The role of a psychologist in this respect is to support the process of self-help or SPI function, which socially means an enrichment of the culture of coping strategies (or the change and the flow of "anti-bodies"). In few of our studies we analyzed the cases of integration of personally unaccepted experience into a few innovative pedagogical and therapeutic technologies of personal growth (Lushyn, 2013). Among which are psychotherapeutic modalities like EMDR (Shapiro, 2018), which was discovered as a social and a very paradoxical individual response to a very challenging/pathological situation of its author and "ecofacilitation" (Lushyn, 2017; Lushyn, 2013), which in itself is a form of sustaining the flow of transitional forms producing the "antibodies"/emergents that lead to full functioning of a person. These and many other therapeutic modalities, techniques and self-healing strategies or trajectories may enrich the ever-transcending culture of illness as a source of development.

A case of buffer transition in the context of psychological help. A woman of 55 survived the death of her son and has been under psychiatric supervision for more than two years. She decided to search for psychological help. The client provided a description of her case as serious enough to stay continuously medicated. At the beginning of the psychotherapeutic session she looked very depressed, and desperate, a number of post-trauma symptoms were still too evident. After establishing a working alliance, the psychologist inquired if the client encountered strange, surprising or paradoxical situation/s during the long period of grieving and treatment. She recalled one when she was asked by her friend to join her at a summer vacation. That was supposed to be a temporary relief from her grieving and depression as she had not left the town since the tragedy. Although it was quite a challenge to convince her, the client accepted her friend's offer. Her psychiatrist was totally against the possibility of "an - extreme - self healing - attempt - with - quite a-critical-perspective". Such an unprecedented break in her scheduled life-style turned out to be a big surprise, and not only for the doctor but for the client herself. Later this ambivalent situation transformed into a life change event. But before that another and even more extraordinary and illogic situations/events happened to her. Having arrived to the destination, the woman was delighted to start long forgotten routines of leisure and relaxation. By the end of the first day she realized having clean forgotten about the prescribed routine medication and consequently was very frightened of a withdrawal syndrome. Finally, by the end of her stay at the resort she found the vacation very good, she felt recuperated and even rehabilitated. On her arriving back home all of the traumatic symptoms returned.

During the session the contradictions and incongruences continued. On the one hand she went 
on crying, complaining about her misfortunes, and the inability to stop her condition, on the other - she persisted to fix her makeup as if trying to produce an impression of being well and healthy. She was asked about the resources to present herself pro-socially and keep up her image. There again followed a rather unexpected response: "The resource that keeps me alive is my work. I am completely engaged into it, otherwise I wouldn't have made it (there had been no indication she could work hard):

- For how long does your working day last?

- About 8 hours a day!

- Does it mean you can stay effective during the day for that long?

- Right, now I even do not notice being slow and somehow impeded by the medicines. But a real challenge or even torture is to be back home after work.

- Are you saying it is bad memories or anything else associated with the loss of your son?

- (There was more of unexpectedness... the client stopped to narrate about her suffering). Not exactly, it is my mother. We live together since my son's death. She is in a pretty bad shape, not exactly physical. She is very pushy and controlling, always searching for a chance to start preaching to me...4-5 hours of my time meant for relaxation after work are wasted on nasty quarrels and family argument... as if I were a little child.

Through a rhythmic flow of contradictions and their resolution the problem of traumatic grieving evolved into the issue of mother-daughter relations at the end of the working day:

- I am very well aware of the fact the best outcome for me would be to separate and live apart. I would be taking good care of my mother if I had my private space and a couple of hours just for myself.

- How come? It is the first time you mentioned the quality of your life...

- I thought of this but once, I mean... renting an apartment in the neighborhood would be a good solution...

After the session the condition of the client changed for the better considerably, she started to work on reducing her medication and had four more psychotherapeutic sessions to find herself as functional as she used to be.
Comments. The above narrative of the case with some highlights underline the positive role of transitional forms like paradoxes, contradictions, incongruences (as compared to negative or positive experiences or responds of the client in traditional or positive psychology, accordingly). They are a precondition and/or a source of the developmental process of self-healing: not only transitional forms but the reconstruction/the "defibrillation" of their rhythm of change. Close attention and appreciation of the full spectrum of person's response, including those that in many modalities are regarded ambiguous and even pathological may transform the undesired experience within a single therapeutic session. A rather unexpected question about ambiguous or paradoxical experience/s during the period of psychiatric treatment and post-traumatic suffering appeared to be a turning point which broke the vicious circle of the pathological response with an access to a different level of personal selfdevelopment or post-traumatic growth (Tedeschi, 2004).

Further we would like to pose a list of questions for the perspective analysis and research.

- Can we conceptualize a successful individual with attributes both of disability/disorder and at the same time characterized by mental as well as social health and wellbeing?

- What resources inspire unhealthy and/or the chronically ill to accumulate power and stay in a constant search of coping strategies in order to preserve or attain the existing or even higher level of functioning?

- What is the source of happiness and wellbeing of people diagnosed with a disease or a serious disorder? Has it to do with a longing for remission and/or relief? If there is something positive besides a daily survival practices that helps the chronically ill further transit into more challenging and developmental contexts?

- In case the subject is aware of his/her major health problem, from what does it offer him a release/freedom? Could it mean that her future is no longer ambiguous and that there is no need to tolerate it, which in itself is a universal human challenge?

- If it happens so that all of a sudden, the pain or even the illness disappears, what remains then? Is it 
just bad memories and flashbacks, or a feeling of relief, or lessons learned as well as an experience of victory or maybe a personal culture/a potential for future transitions and growth?

- If so, could people with serious illness and damage be the owners of a greater potential or even be more gifted as compared to those devoid of survival or extreme experiences?

- If there exists a culture of health - a part of the human culture that helps people sustain a certain level of functioning - then, is there a "culture of illness" which can also be defined in terms of values and deliberate practices of "positive suffering" being appropriated and communicated throughout generations, groups and communities?

- If historically the appearance of different disorders and illnesses stimulated the appearance of various forms of medical, psychological or social treatments, can we interpret the culture of illness and disorder as closely connected not only to human's will to survive but also to health and wellbeing in terms of psychosocial growth and development?

- In this developmental context the culture of illness constitutes a transitional form to a different or even innovative mode of living and consequently understanding of health, which is more psychosocial and biotechnological. Given the contemporary human has been integrating the advantages of the human culture, could it be appropriate to reconsider her/him in terms of a "biosocial cyborg" whose health and immunity is no longer localized within a somatic but a social form equipped by historically verified means of self-regulation and development?

\section{Conclusion}

By means of theoretical as well as empirical analysis we distinguished a special sphere of psychology with its major task to resolve the contradiction between Traditional (Negative) and Positive Psychology. It claims that both are complementary as well as dialectically interdependent predispositions for the change and development of socio-cultural matrix of psychological knowledge.

Buffer Psychology or Psychology of Transition could be interpreted as closely associated with the so called Traditional and Positive Psychology presuming that any experience of a person can have positive/non- deficient nature: critical as well as positive experiences are viewed in terms transitional phenomena facilitating the logic of personal and social development and growth - thesis-antithesis-synthesis. Development and growth constitute the principal content of health and well-being, while its elements of discomfort, suffering as well as thriving and happiness being integral to the totality of the psycho-social self-organizing ecosystem. Buffer Psychology supports the idea that psychosocial ecosystems enjoys a certain capacity for an immunity response (gene-antigen-antibody) which is not restricted or reduced to its subject, it is not localized by a person, group or a community, their psychological, physical, biological or transcendental structure. The moment of disorder/deficiency or rupture within an ongoing condition of development promotes an immunity non-deficiency response (SPI) in the form of psychological, psychosomatic or social "antibodies" or spontaneous coping strategies. The ecosystem expands its boundaries by absorbing/generating novel elements from the environment. Consequently, psychological, pedagogical or any other forms of communication and help could be interpreted in terms of consolidation of the human and system's potential. Thus, Buffer Psychology could be related to both Positive Psychology, and Traditional Psychology considering negative and positive conditions as facilitating growth and development of the open ecosystem.

\section{References}

Bauman, Z. (2010). 44 Letters from the Liquid Modern World. Cambridge.

City of translators. (2007). PilsudskiJ., from http://www.trworkshop.net/forum/viewtopic.php?f=66\&t $=28902$

Csikszentmihalyi, M. (2012). FLOW: The Psychology of Optimal Experience.

Davis, R. D., \& Millon, T. (1994). Personality change: Metatheories and alternatives. In T. F. Heatherton \& J. L. Weinberger (Eds.), Can personality change? (pp. 85-119). American Psychological Association. https://doi.org/10.1037/10143-005

Fassinger, R. E. Shullman, S. L., Buki, L. P. (2017). Future Shock: Counseling Psychology in a VUCA World. Counseling Psychologist, 45(7) 1048-1058, https://doi.org/10.1177/0011000017744645

Fava, G., Guidi, J. (2020). The pursuit of euthymia. Forum The Evolving Science of Euthymia: Concepts, Assessment and Interventions. World Psychiatry. 19(1), 40-50. https://doi.org/10.1002/wps.20698

Greenberg, G. (2010). Inside the Battle to Define Mental Illness from: http://www.wired.com/magazine/2010/12/ff_dsmv/. 
Hegel, G. W. F. (1812/1969). Science of Logic (A. V. Miller, Trans.). London: George Allen and Unwin.

Held, B. (2004). The Negative Side of Positive Psychology. Journal of Humanistic Psychology, 44(1), 9-46.

Jans-Beken, L. (2019). The dialectic dynamics between trait gratitude, subjective well-being, and psychopathology across 30 weeks, Counselling Psychology Quarterly, https://doi.org/10.1080/09515070.2019.1638228

Seligman, M. E. P. (2000). Mihaly Csikszentmihalyi, American Psychologist, 55(1), 5-14, https://doi.org/10.1037//0003066X.55.1.5

Kostyuk, G. (1989). Learning process and mental development of a person. (In Ukranian)

Kenny, V., Gardner, G. (1988). Construction of self-organizing systems. Irish Journal of Psychology. 9, 25-82.

Linden, M. (2020). Euthymic suffering and wisdom psychology. World Psychiatry, 1, 55-56: https://doi.org/10.1002/wps.20718

Lomas, T., Ivtzan, T. I. (2015). Second wave positive psychology: Exploring the positive-negative dialectics of wellbeing. Journal of Happiness Studies. https://doi.org/10.1007/s10902-015-9668-y.

Lushyn, P. (2017). Chaos and ambiguity: from suffering to growth. (In Russian)

Lushyn, P. (2013). Ecopsychological facilitation in the transition period (In Russian)

Masterpasqua, F., \& Perna, P. A. (Eds.). (1997). The psychological meaning of chaos: Translating theory into practice. American Psychological Association. https://doi.org/10.1037/10240-000.

Miller, A. (2008). A Critique of Positive Psychology - or 'The New Science of Happiness'. Journal of Philosophy of Education, 42(3-4), 591-608.

Mack, O., Khare, A., Kramer, A., Burgartz, T. (2015). Managing in a VUCA.

Miller, S., Hubble, M. (2011). The road to mastery. The psychotherapy networker, 15(2), 22-31.
Mills, J. (2000). Dialectical psychoanalysis: Toward process psychology. Psychoanalysis \& Contemporary Thought, 23(3), 417-450.

Nurul Atika Mohd Rosli, Zilal Saari, Talhah Ajmain, Fatin Nabilah Abu Hassan, Aminudin Hehsan, Farahwahida Mohd Yusof, Zety Azlin Elias, Nur Najwa Hanani Abd Rahman, (2020). How happy are you? Defining happiness in industrial revolution 4.0. Journal of Critical Reviews. 7(13), 1194-1199. https://doi.org/10.31838/jcr.07.13.205.

Pervin, E. (1990). Handbook of personality: theory mand research.

Prigogine, I., Stengers, I. (1984). Order out of chaos. - New York: Bantam.

Rowen, J. (1992). The Concept of breakthrough Breakthrough and Integration in Psychotherapy, 81-83.

Shapiro, F. (2018). Eye movement desensitization and reprocessing (EMDR) therapy: Basic principles, protocols, and procedures ( $3 \mathrm{rd}$ ed.). The Guilford Press.

Smith, R. (2008). The end of disease and the beginning of health. from: https://blogs.bmj.com/bmj/2008/07/08/richardsmith-the-end-of-disease-and-the-beginning-of-health/

Tedeschi, R. G., Calhoun, L. G. (2004). A clinical approach to posttraumatic growth. Positive psychology in practice. pp. 405-419.

Toriqul, C. M. (2018). Positive psychology: personalities, major issues, advantages and disadvantages. Muaddib : Studi Kepen didikan dan Keislaman, [S.1.], 8(1), 34-53, https://dx.doi.org/10.24269/muaddib.v8i1.1048.

Wieland-Burston, J. (2015). Chaos and Order in the World of the Psyche. https://doi.org/10.4324/9781315682778.

Wong, P., Roy, S. (2017). Critique of positive psychology and positive interventions. International handbook of critical positive psychology.

Von Bertalanffy, L. (1967). General theory of systems: Application to psychology. Social Science Information, 6(6), 125-136. https://doi.org/10.1177/053901846700600610

\section{У ВИТОКІВ ПСИХОЛОГЇ̈ ПЕРЕХОДУ: НА СТИКУ ТРАДИЦЙНОЇ ТА ПОЗИТИВНОЇ ПСИХОЛОГІї} Павло Лушин

Вищий державний навчальний заклад «Університет управління освітою» НАПН Украӥни Навчально-науковий інститут менеджменту та психології Кафедра психології та розвитку особистості вул. Січових Стрільиів. 52 А, Київ, 04053, Украӥна

Стаття пропонує цілісне або, точніше, голографічне уявлення про розвиток психології на етапі іiі критичної самоорганізації в епоху непередбачуваного, динамічного, складного і невизначеного світу (VUCA-world). Прикладом такої самоорганізації $\epsilon$ поява (20 років тому) Позитивної психології (ПП). Автор доходить до висновку про зародження в іiї контексті нового напряму психологічних досліджень і практики - так званої «Буферної психології» або «Психології переходу». Її зміст розглядається в єдності трьох методологічних основ: діалектичному, психоімунологічному і клінічному. Якщо Позитивна психологія займається вивченням позитивних сторін життя людини, здоров'ям, то традиційна психологія концентрується на дослідженні і усунення негативних факторів і сторін життя людини. Психологія переходу або Буферна психологія спирається на положення про те, що будь-яке переживання людини, включаючи і болісне, може мати конструктивний зміст, недефіцитарну природу. Автор статті розділяе уявлення про те, що імунна система або соціально-психологічний імунітет особистості за своєю суттю є нелокалізованою тільки тілом або свідомістю окремої людини чи групи. Це відкрита динамічна $\mathrm{i}$ самоорганізуюча соціальна екосистема. У момент "порушення" (дефіциту) сформованого способу функціонування та розвитку "соціальний психоімунітет" (СПI) профіцитарно спрацьовує, включаючи елементи середовища, яких бракує, і тим самим забезпечує стабілізацію системи особистості чи спільноти. Допомога в Психології переходу - сприяння СПІ в момент або в ситуації, коли агента допомоги включають в черговий етап або виток саморозвитку СПІ. Екофасилітація як вид допомоги - підтримка стану розвитку СПІ, як на рівні окремої людини, так і соціальної екосистеми в цілому. У статті розглянуто та проаналізовано випадок недефіцитарної допомоги з ефектом посттравматичного зростання (в межах нового напряму психологічної практики), розглянуті перспективи розвитку Психології переходу.

Ключові слова: VUCA-світ, Позитивна психологія, Традиційна психологія, Буферна психологія або Психологія переходу, психологічна практика, принцип недефіцитарності, екосистема, соціальний психоімунітет, екофасилітація, посттравматичне зростання. 